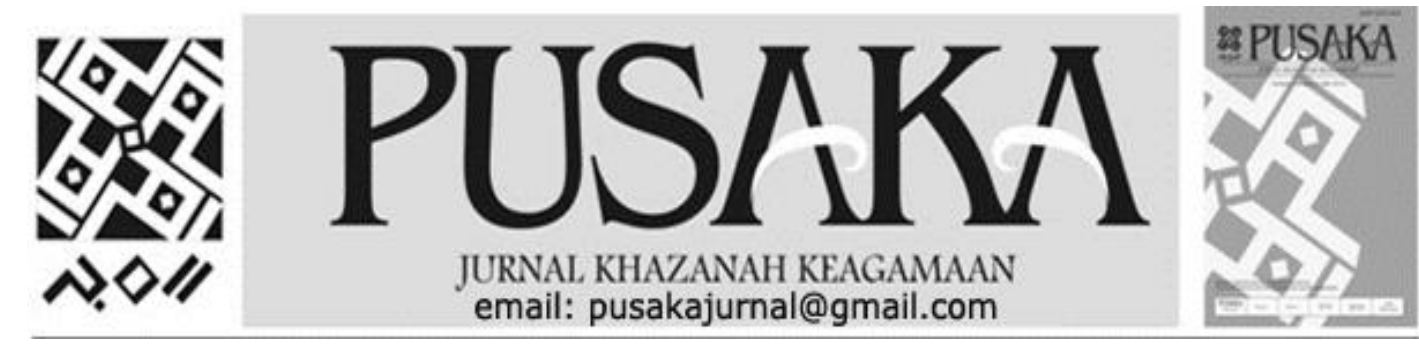

\title{
Praktik Pencatatan Ijab Qabul Via Online dalam Proses Akad Nikah Di Makassar
}

\section{The Implementation of Ijab Qabul Via Online about Nikah Event in Makassar}

\section{Faizal Bachrong}

Balai Penelitian dan Pengembangan Agama Makassar

Jl. AP. Pettarani No. 72 Makassar

Email: faizalbachrong@gmail.com

\section{Fathur Marzuki dan Handar Subhandi Bakhtiar}

Universitas Hasanuddin Makassar

Jl. Perintis Kemerdekaan KM.10

Email: fathurmarzuki@gmail.com, handarsubhandi@gmail.com

\begin{tabular}{|c|c|}
\hline $\begin{array}{c}\text { Info } \\
\text { Artikel }\end{array}$ & Abstract \\
\hline $\begin{array}{c}\text { Diterima } \\
28 \\
\text { Februari } \\
2019 \\
\\
\text { Revisi I } \\
15 \\
\text { Maret } \\
2019 \\
\\
\text { Revisi II } \\
29 \\
\text { Maret } \\
2019 \\
\\
\text { Disetujui } \\
1 \\
\text { Mei } \\
2019\end{array}$ & $\begin{array}{l}\text { Perkembangan teknologi yang merambah ke seluruh sendi kehidupan manusia } \\
\text { membawa perubahan terhadap budaya masyarakat khususnya dalam proses } \\
\text { pernikahan. Pernikahan yang menuntut proses akad nikah yang secara langsung } \\
\text { dihadiri oleh seluruh pihak baik mempelai laki-laki, mempelai perempuan, wali } \\
\text { dan saksi mulai terjadi pergeseran yang tajam. Pelaksanaan ijab qabul via online } \\
\text { menjadi sebuah cara baru dalam proses akad nikah. Ijab qabul via online menurut } \\
\text { penafsiran hukum Islam terjadi perbedaan pendapat sehingga pelaksanaan } \\
\text { pencatatan nikah khususnya nikah dengan ijab qabul via online juga terjadi } \\
\text { perbedaan pendapat. } \\
\text { Kata kunci : Ijab Qabul Online, Akad Nikah, Pencatatan Nikah. } \\
\text { Technological developments that penetrate throughout the joints of human life } \\
\text { bring changes to the culture of society, especially in the marriage process. A } \\
\text { marriage that demands a marriage contract process which is directly attended by } \\
\text { all parties, both the bridegroom, bride, guardian and witnesses, begins a sharp } \\
\text { shift. The implementation of the ijab qabul via online is a new way of getting } \\
\text { married. Ijab qabul via online according to the interpretation of Islamic law there } \\
\text { was a difference of opinion so that the implementation of marriage registration, } \\
\text { especially marriage with ijab qabul via online also occurred differences of } \\
\text { opinion. } \\
\text { Keywords: Qabul Online Ijab, Marriage Contract, Marriage Registration. }\end{array}$ \\
\hline
\end{tabular}




\section{PENDAHULUAN}

Pada hakikatnya seluruh makhluk ciptaan Allah Swt. merupakan ciptaan yang sempurna, dan manusia merupakan ciptaan paling sempurna di antara yang lainnya. Kesempurnaannya dapat dilihat mulai dari bentuk tubuhnya yang tampak secara kasat mata, kemudian organ-organ penting yang ada di dalam tubuh manusia yang tertata sedemikian rapi nan lengkap, penganugerahan akal pikiran serta alat untuk berkomunikasi satu sama lain antar sesama. Kesempurnaannya sebagai makhluk ciptaan Allah Swt. ini diabadikan oleh Allah Swt. di dalam AlQurannya Q.S At-Tin Ayat 4 "Laqod' kholaknal insana fi ahsani taqwim yang artinya "Sesungguhnya kami telah menciptakan manusia dalam bentuk yang sebaik-baiknya" (Tihami dkk., 2009: 6).

Manusia yang dikaruniai dengan akal pikiran tentu saja memiliki tugas dan tanggung jawab yang lebih besar dibanding dengan makhluk ciptaan lainnya. Dengan sejumlah kelebihan yang ada, mulai dari kesempurnaan fisik dan tanggung jawab tidak dapat menutupi kekurangan dan keterbatasannya sebagai makhluk ciptaan dan makhluk sosial yang membutuhkan individu lain dalam kehidupannya untuk terus berkembang dan mempertahankan eksistensi kemanusiaannya. Salah satu cara yang dapat dilakukan oleh manusia untuk terus mempertahankan eksistensinya adalah melalui perkawinan.

\section{Perkawinan}

merupakan

sunatullah yang umum dan berlaku pada semua makhluknya, baik pada manusia, hewan maupun tumbuh-tumbuhan. Perkawinan merupakan cara yang dipilih dan dianjurkan oleh Allah Swt. sebagai salah satu jalan untuk melestarikan hidupnya selain mempertahankan eksistensinya (Abidin dkk., 1999: 9).

Anjuran melaksanakan perkawinan begitu banyak baik itu berupa Dalil Quran dan hadis Nabi Saw. Namun tidak serta tanpa syarat sehingga semua orang bisa melaksanakannya kapan dan di mana saja. Dalam berbagai literatur dan pendapat ulama, perkawinan mempunyai rukun syarat yang harus dipenuhi oleh calon yang akan melaksanakan perkawinan itu. Adapun di antaranya yang telah menjadi ketentuan baku atau telah menjadi rukun syarat yang disepakati jumhur ulama maupun UU di negara kita adalah sebagai berikut:

1. Mempelai laki-laki

2. Mempelai perempuan

3. Wali

4. Dua orang saksi

5. Ijab qabul

Dengan adanya rukun yang telah ditetapkan menjelaskan bahwa perkawinan yang tidak memenuhi rukun yang telah ditetapkan menjadi perkawinan tersebut tidak sah secara hukum. Salah satu rukun perkawinan yang menjadi tanda kesepakatan terjadinya penyerahan dan penerimaan dari kedua belah pihak adalah terlaksananya akad nikah dalam bentuk Ijab Qabul itu sendiri.

Seperti yang diketahui pada umumnya ijab adalah penyerahan dari pihak pertama (wali perempuan), sedangkan qabul adalah penerimaan dari pihak kedua (mempelai laki-laki). Dan dalam hukum Islam sebagaimana yang terdapat dalam kitab-kitab fiqhi 
klasik dan kontemporer ijab qabul merupakan perjanjian kuat yang tidak boleh disamakan dengan perjanjian keperdataan pada umumnya. Sebab, perjanjian kuat ini diabadikan dalam AlQuran dengan ungkapan 'Mi tsaqon Gholizon' yang mana perjanjian itu bukan hanya disaksikan oleh dua orang saksi yang ditentukan atau orang banyak yang hadir pada waktu berlangsungnya ijab qabul, tetapi juga langsung disaksikan oleh Allah Swt. (Syarifuddin, 2014: 62)

Beberapa ulama sepakat ijab dan qabul itu sebagai rukun perkawinan sehingga syarat pelaksanaannya harus sesuai tuntunan yang telah ditetapkan, yakni kejelasan pelaku yang melaksanakan serta kejelasan apa yang diucapkannya. Dan UU perkawinan tidak mengatur itu secara detail. Sehingga regulasi pengaplikasiannya masih sangat belum jelas. Apalagi menghadapi tuntunan zaman yang sudah semakin kompleks di era digital ini.

Di abad 21 atau biasa disebut era milenial, berbagai sisi terus mengalami perkembangan atau sentuhan digital. Begitupun dalam proses ijab qabul dalam perkawinan. Di mana ada model fenomena baru yang lagi viral di masyarakat yakni pengucapan ijab dan qabul via media online. Adapun beberapa contoh pelaksanaan ijab qabul via online dalam proses akad nikah yakni pernikahan seorang anggota polwan yakni Briptu Nova yang merupakan anggota polda Kalimantan Barat Ijab Qabul Lewat Video Call, https://m.detik.com/news/berita/d39960 92/kisah-haru-polwan-ijab-qabul-lewat -video-call, (diakses diakses pada 16 Maret 2019, pukul 23.37). Perkawinan ini viral bulan April tahun 2018 lalu, di mana ceritanya briptu nova juga tengah menjalani tes seleksi untuk bergabung sebagai United Nation Police (polisi PBB) di Puslat Multi Fungsi Polri Cikeas, Jawa Barat. Kegiatannya bertepatan dengan proses akad dan resepsi pernikahannya yang di mana hal ini di luar dari prediksi nova sendiri. Begitu juga pada kasus yang telah diputuskan oleh Pengadilan Agama Jakarta Selatan No. 1751/P/1989 tentang pengesahan Ijab Qabul melalu media online.

Hal ini tentunya harus menjadi perhatian lebih dari pemerintah dan pihak terkait agar sekiranya dapat memberikan kejelasan regulasi terhadap fenomena kontemporer ini. Sehingga ke depannya peristiwa-peristiwa perkawinan yang terlaksana seperti demikian mempunyai kekuatan hukum yang jelas dan kuat serta diakui oleh negara.

\section{METODE PENELITIAN}

Penelitian ini termasuk field research (Data Lapangan). Data yang didapatkan dianalisis secara kualitatif kemudian disajikan secara deskriptif. Lokasi Peneitian di Makassar, dengan sasaran seluruh Kantor Urusan Agama di Kota Makasar dan Lembaga Fatwa pada Organisasi Masyarakat Islam yang populer.

Untuk mendapatkan data yang relevan, teknik pengumpulan data yang digunakan dalam penelitian ini adalah wawancara, observasi dan dokumentasi.

\section{Tinjauan Umum Akad Nikah}

Akad nikah adalah perjanjian yang berlangsung antara dua pihak yang melangsungkan perkawinan dalam bentuk Ijab dan qabul. Ijab adalah penyerahan dari pihak pertama (wali 
perempuan), sedangkan qabul adalah penerimaan dari pihak kedua (pihak mempelai laki-laki). Akad nikah itu sendiri juga tentunya didasarkan atas perasaan suka sama suka atau rela sama rela, dan karena perasaan rela sama rela itu adalah hal yang sifatnya tersembunyi dan tidak tampak maka sebagai manifestasinya adalah ijab dan qabul.

Sebutan aqad nikah berasal dari Al-Quran yakni aqdu al nikah dibaca aqdun nikah yang sudah biasa kita sebut sebagai akad nikah. Akad secara bahasa artinya adalah ikatan, sedangkan nikah berarti perkawinan. Jadi akad nikah berarti perjanjian mengikatkan diri dalam perkawinan antara seorang lakilaki dan perempuan (Thalib, 2014: 63)

Dalam hal hukum perkawinan, dalam menempatkan mana yang rukun dan mana yang syarat terdapat perbedaan di kalangan ulama yang perbedaan ini tidak bersifat substansial. Perbedaan di antara pendapat tersebut disebabkan oleh karena berbeda dalam melihat fokus perkawinan.

Menurut jumhur ulama, Rukun merupakan hal yang menyebabkan berdiri dan keberadaan sesuatu. Di mana sesuatu itu tidak akan terwujud melainkan dengannya. Atau dengan kata lain merupakan hal yang harus ada dan penentu esensi sesuatu (Az-Zuhaili, 2007: 45).

Ketentuan baku rukun dan syarat nikah yang disepakati jumhur ulama maupun UU di negara kita adalah sebagai berikut: mempelai laki-laki, mempelai perempuan, wali, dua orang saksi dan ijab qabul (Rahayu, 2017: 24). Kelima rukun nikah ini, yang paling penting ialah Ijab dan Qabul antara yang mengadakan dengan menerima akad. Sedangkan yang dimaksudkan dengan akad adalah syarat yang bertalian dengan rukun-rukun perkawinan yaitu syarat-syarat bagi calon mempelai, wali saksi, dan ijab qabul (Abidin dkk., 1999: 12).

Ijab dan qabul disebut sebagai manifestasi dari perasaan rela sama rela juga sekaligus menjadi unsur mendasar bagi keabsahan akad nikah. Di mana ijab diucapkan oleh wali sebagai pernyataan rela menyerahkan anak perempuannya kepada calon suami dan qabul diucapkan oleh calon suami sebagai pernyataan rela mempersunting calon istrinya (Effendi, 2010: 2-3). Lebih jauh lagi, ijab berarti menyerahkan amanah Allah kepada calon suami dan qabul berarti sebagai lambang bagi kerelaan menerima amanah Allah tersebut. Dengan ijab qabul yang tadinya haram menjadi halal.

\section{Ijab Qabul Via Online Menurut Hukum Islam dan Hukum Positif Indonesia}

Ijab qabul dalam proses akad nikah dulu pada umumnya dilaksanakan dalam sebuah majelis yang sama yang mana antara si pengucap ijab dan qabul berinteraksi langsung saling bersalaman satu sama lain sebagai simbol kemufakatan layaknya si pemberi dan penerima sesuatu saat transaksi jual beli. Namun seiring perkembangan zaman yang semakin modern, muncul sebuah problematika kontemporer, yakni penggunaan media onlie sebagai alat untuk mengucap ijab dan qabul antara wali dan calon suami (Rahman dan Faiza, 2014: 37).

Biasanya dalam ijab qabul umumnya antara pihak laki-laki dan perempuan dapat bertemu, bertatap muka dan berbicara secara langsung, begitupun dengan ijab qabul via online. Pada penerapan atau pelaksanaannya ijab qabul via online ini menggunakan 
kekuatan dari perkembangan teknologi (Farid, 2018: 179). Hal ini untuk mensiasati teknis pelaksanaan akad nikah agar lebih mudah, sebagaimana syarat-sarat dalam prangkat budaya yang dianggap menyulitkan dapat disiasati dengan kesepakatan antara kedua pihak keluarga, demi kelancaran proses akad nikah. Sepanjang tidak menggugurkan ketentuan yang sudah qath'i (Muslim, 2014: 67). Inti dari nikah online adalah untuk membantu suksesnya nikah agar dapat menyampaikan gambar kondisi individu yang sedang melakukan interaksi sebagaimana mestinya. Teknologi video teleconference atau Video Call dll lebih mutakhir dari telepon, karena selain menyampaikan suara, teknologi ini dapat menampilkan gambar atau citra secara realtime melalui jaringan internet.

Ijab qabul via online ini sendiri dapat difasilitasi dengan menggunakan proyektor (alat tembak) ke layar besar untuk menampilkan masing-masing pihak dan unsur-unsur yang ingin melangsungkan akad nikah. Hal ini untuk membuktikan dan membuat semua orang dapat melihat akad sebagaimana bertemu, berjumpa, bertatap muka secara langsung dan khususnya agar sebagaimana mestinya, serta disertakan juga alat pengeras suara sehingga semua orang dapat mendengar secara jelas sebagaimana yang dikehendaki pada nikah umumnya.

Adapun unsur pokok yang mendukung dan memperkuat pelaksanaan akad ini ialah ia menggunakan basis internet atau server sebagai alat kerjanya, yang dibantu dengan webcame, aplikasi-aplikasi TIK, seperti aplikasi otomatis perkantoran, surat elektronik, SMS, forum, knowledge, website, melalui fasilitas komunikasi telepon, internet maupun global internet dan sebagainya dalam hal penerapannya.

Dalam Al-Qur'an, Hadist maupun kajian kitab fiqhi klasik diskursus problematika khusus seperti ini mungkin tidak akan ditemukan. Karena tema pembahasannya bukan terkait medianya, namun bersatu majelis atau tidaknya pengucapan ijaab qabulnya atau dalam istilah ittihad al majlis (Muslim, 2015: 191).

Dalam beberapa kitab fiqhi baik itu ulama klasik maupun kontemporer seperti 4 imam madzhab dan ulama pengikutnya, abdurrahman al jaziri, Wahbah az zuhaili, Said sabiq membahas terkait 'ittihad al majelis' ini. Seperti dalam yang dituliskan Abdurrahman al-Jaziri dalam kitabnya al-fiqh ala Mazahhib al ar'bah menyatakan bahwa dalam menafsirkan ittihad al majlis itu terdapat dua penafsiran yakni:

Pertama, yang dimaksud dengan ittihad al majelis ialah bahwa ijab dan qabul harus ada kesinambungan dan berarti tidak boleh ada perbuatan/ucapan lain yang membatasi antara ijab dan qabul. namun tidak disyaratkan satu tempat. Said sabiq dalam kitabnya Fiqhi as-Sunnah dalam menjelaskan arti bersatu majelis bagi ijab dan qabul lebih menekankan kepada pengertian tidak boleh terputusnya antara ijab dan qabul atau dalam artian tidak ada perbuatan dan ucapan lain yang memperantarai keduanya. Satu contoh dikemukakan oleh Al Jaziri dalam memperjelas pengertian bersatu majelis yang juga hampir sama ditafsirkan oleh Said Sabiq yakni dalam mazhab Hanafiah. Di mana seorang lelaki berkirim surat mengakadkan nikah kepada pihak perempuan yang dikehendakinya. 
Setelah surat itu sampai, lalu isi surat itu dibacakan di depan wali wanita dan para saksi dan dalam majelis yang sama setelah surat itu dibacakan wali perempuan langsung mengucapkan penerimaannya (kabulnya). Praktik akad nikah seperti itu menurut kalangan Hanafiah dianggap sah (Satria dkk., 2010: 31).

Kedua, ialah pendapat yang mengatakan bahwa bersatu majelis diisyaratkan buka saja untuk menjamin kesinambungan antara ijab dan qabul tetapi sangat erat hubungannya dengan tugas dua orang saksi yang menurut pendapat ini, harus dapat melihat dengan mata kepalanya bahwa ijab dan qabul betul-betul diucapkan oleh kedua orang yang melakukan akad. Karena seperti yang diketahui bahwa salah satu rukun syarat sahnya sebuah akad adalah dihadirinya oleh dua orang saksi (Satria, 2010: 6).

Dari penjelasan di atas secara tegas dapat dipahami bahwa adanya persyaratan bersatu majelis (waktu dan tempat), bukan hanya untuk menjaga kesinambungan waktu, tetapi juga mengandung maksud lain yakni al muayyanah yaitu kedua bela pihak sama-sama hadir dalam satu tempat (Helim, 2012: 2753), karena dengan itu persyaratan dapat melihat secara nyata pengucapan ijab dan qabul dapat diwujudkan.

Sedangkan Jika merujuk ke dalam UU Perkawinan nomor 1 tahun 1974 tidak terdapat penjelasan secara detail tentang akad nikah. Adapun yang menjelaskannya ada di dalam Kompilasi Hukum Islam yang terdapat pada bagian kelima pasal 27, 28 dan 29. Di mana dalam Pasal 27 dituliskan bahwa 'Ijab dan Qabul antara wali dan calon mempelai pria harus jelas beruntun dan tidak berselang waktu, dalam pasal 28 dituliskan bahwa 'akad nikah dilaksanakan secara pribadi oleh wali bersangkutan. Wali dapat mewakilkan kepada orang lain'. Dan Pasal 29 ayat (1) ditulis bahwa yang berhak mengucapkan qabul ialah calon mempelai pria secara pribadi, kemudian ayat (2) Dalam hal hal tertentu ucapan qaabul nikah dapat diwakilkan kepada pria lain dengan ketentuan calon mempelai pria memberi kuasa yang tegas secara tertulis bahwa penerimaan wakil atas akad nikah itu adalah untuk mempelai pria.

Namun, hal yang perlu diketahui terkait problem kontemporer ini ternyata sudah pernah dikaji dan diputus oleh Pengadilan Agama Jakarta No.1751/P/1989 tentang Pengesahan perkawinan Lewat Telepon. Hal ini tentu secara tidak langsung memberikan referensi baru untuk bagaimana memandang ijab qabul via online ini.

\section{Ijab Qabul Via Online dalam Berbagai Pandangan}

Terkait ijab qabul via online ini, beberapa pandangan lembaga fatwa masing-masing perwakilan ormas besar yang ada diwilayah Kota Makassar, yang mempunyai pandangan khusus terkait fenomena kontemporer ini. Masing-masing pandangan diuraikan sebagai berikut:

1. Majelis Ulama Indonesia (MUI) Kota Makassar

Menurut MUI Kota Makassar yang disampaikan oleh AGH.KH. Baharuddin As dalam wawancaranya mengatakan bahwa terkait Ijab Qabul via online itu sendiri sebenarnya sudah menjadi perdebatan Ulama-Ulama terdahulu namun temanya bukan terkait kesahihan pengucapannya melalui media onlinenya tetapi satu majelis atau tidak satu majelisnya. 
Gurutta

Baharuddin

melanjutkan bahwa Ijab Qabul Via

Online itu sah sah saja, yang terpenting memenuhi syarat dan rukun pernikahan, orang-orang yang mengucap ijab dan qabul jelas (diketahui secara jelas rupanya) dan Saksi menjadi penyaksi ijab di kedua belah pihak menjalankan tugasnya menyaksikan pengucapan ijab dan qabul yang dilakukan kedua belah pihak.

2. Nahdlatul Ulama Sulawesi Selatan

Menurut Dr. Muammar Bakri Lc. selaku perwakilan Pengurus Wilayah Nahdlatul Ulama Sulawesi Selatan yang juga menjabat sebagai wakil ketua PWNU Sulsel menjelaskan bahwa Ijab Qabul via online bisa saja dilaksanakan asalkan ada kepastian dari pengucap ijab dan qabul itu secara fisik, saksi yang menyaksikan pengucap ijab dan qabul. dan kalau secara fiqhi yang terpenting Rukun dan syaratnya terpenuhi.

3. Muhammadiyah Sulawesi Selatan

Menurut Dr. Abbas Baco M. Lc,. MA sebagai Sekretaris Majelis Tarjih dan Tajdid Pengurus Wilayah Muhamadiyah (PWM), menjelaskan bahwa Akad nikah sah secara syar'i jika memenuhi rukun dan syarat-syaratnya. Menurut jumhur ulama rukun dan syaratnya ada lima yakni adanya mempelai pria, mempelai wanita, wali nikah, hadirnya dua orang saksi dan akad ijab dan qabul. Kemudian masingmasing rukun tersebut ada syaratnya. Khusus ijab qabul ada 4 syarat:

1. Ijab dan qabul dilakukan dalam satu majelis.

2. Kesesuaian ijab dan qabul.

3. Yang melaksanakan ijab (wali) tidak menarik kembali ijabnya sebelum qabul dari pihak lain (calon suami).
4. Berlaku seketika, dalam artian tidak boleh dikaitkan dengan masa yang akan datang.

Yang dimaksud dengan ijab qabul dilakukan dalam satu mejelis pada syarat pertama adalah ijab dan qabul terjadi dalam satu waktu. Suatu akad ijab dan qabul dinamakan satu majelis jika satelah pihak wali selesai mengucapkan ijab, calon suami segera mengucapkan qabul. Antara ijab dan qabul tidak boleh ada jeda waktu yang lama. Sebab jika jeda waktu lama antara ijab dan qabul, maka qabul tidak dianggap sebagai jawaban terhadap ijab. Ukuran jeda waktu yang lama, yaitu jeda yang mengindikasikan calon suami menolak untuk menyatakan qabul. Antara ijab dan qabul tidak boleh diselingi dengan perkataan yang tidak terkait dengan nikah sekalipun sedikit, juga sekalipun tidak berpisah dari tempat akad.

Jadi, ijab dan qabul tidak harus dilakukan antara dua pihak dalam satu tempat. Hal ini juga bisa disamakan dengan disahkannya oleh ulama imam mazhab terkait ijab qabul yang dilakukan oleh dua pihak yang berjauhan melalui sarana surat atau utusan. Oleh sebab itu, jika ijab qabul melalui surat saja disepakati kebolehannya oleh ulama mazhab, maka kenapa tidak ijab qabul yang menggunakan fasilitas video call yang faktanya dapat menampakkan wajah dari siapa yang diajak berkomunikasi melalu fasilitas itu.

Dengan demikian akad ijab dan qabul melalui media online (video call, skype dan sejenisnya) sah secara syar'i dengan catatan memenuhi rukun dan syarat akad ijab dan qabul. sekalipun demikian, alangkah baiknya jika dilakukan langsung seperti pada umumnya yang dilakukan secara 
normal dengan mempertemukan masing-masing pihak secara langsung.

Kebolehan dalam pelaksanaan nikah online kemudian perlu dilengkapi dengan aturan hukum yang jelas. Meskipun terdapat pandangan yang mengutamakan pentingnya satu majelis dalam pelaksanaan ijab qabul, yang dilakukan dalam artian saling tatap muka secara pisik. Merupakan sebuah upaya untuk melanjutkan tradisi sakral dalam perkawinan, dan untuk menunjang salah satu fungsi masjid yang banyak digunkan oleh masyaralat untuk acara akad nikah, bahkan bisa menjadi sumber penghasilan yang siginifikan bagi masjid besar, seperti masjid agung atau islamic center (Subair, 2013: 60-61).

Nikah online ini penting untuk diperhadapkan dengan pandangan dari Kepala Kantor Urusan Agama (KUA), atau yang mewakili dalam hal ini penyuluh agama yang ada di masingmasing kantor KUA di kota Makassar selaku aparat pencatat nikah. Karena pandangan dari para kepala KUA tersebut berpengaruh atas pencatatan nikah terhadap kasus yang terjadi ke depannya. Adapun pendapat para kepala KUA adalah sebagai berikut:

1. KUA Kecamatan Biringkanayya Menurut KUA Kecamatan Biringkanayya yang dalam hal ini diwakili oleh Ust. Alwi S.Ag. saat diwawancarai menjelaskan bahwa Ijab Qabul via Online ini secara agama telah sesuai dengan tuntunan Quran, Hadist, dan Fiqhi itu sendiri dan dalam beberapa pendapat banyak yang membolehkan sesuai dengan prinsipnya " $A$ l Islamussholih likulli zaman wa makan”, namun hal yang perlu diketahui di dalam negara kita, terdapat aturan yang mengikat tentang perkawinan. Mulai UU Perkawinan, Peraturan Menteri dan lain-lain terkait pencatatan perkawinan sehingga hal ini tidak serta begitu saja dilegalkan dan dicatatkan. Karena dalam beberapa berkas yang juga menjadi persyaratan administratif diperlukannya keterlibatan kedua calon mempelai, wali, saksi langsung atau tidak bisa terwakilkan. Lanjutnya, dan di KUA kecamatan Biringkanayya ini belum mendapatkan kasus seperti yang diteliti oleh peneliti.

2. KUA Kecamatan Rappocini

Dalam kesempatan wawancara dilakukan di KUA Kecamatan Rappocini, yang mana bersama Kepala KUA kecamatan Rappocini itu sendiri yakni Ust. Yusrin S.Ag. Beliau menjelaskan bahwa pengucapan ijab qabul yang ideal sesungguhnya dan seharusnya itu satu majelis dan satu tempat. Namun jika calon tidak sempat hadir karena suatu hal, maka yang dibenarkan itu hanya memberikan kuasa kepada orang lain agar diwakilkan mulai pengurusan berkas sampai saat pengucapan ijab dan qabul dengan surat kuasa. Hal ini sesuai dengan aturan yang ada di dalam UU Perkawinan itu sendiri.

3. KUA Kecamatan Panakkukang

Pandangan KUA Kecamatan Biringkanayya yang dalam hal ini diwakilkan oleh Ust. Muhiddin S.Ag selaku Penghulu KUA Kecamatan Panakkukang, mengatakan bahwa ijab qabul via online ini efek semakin berkembangnya zaman seperti sekarang ini. Beliau melanjutkan bahwa seperti yang diketahui umumnya di masyarakat dan sesuai UU Perkawinan yang menjadi Rukun dan Syarat perkawinan itu sendiri ada 5 dimulai dari Calon mempelai laki-laki dan perempuan, adanya Wali Nikah, Adanya Saksi dan terakhir adalah ijab qabul. khusus ijab qabul itu sendiri juga punya syarat, di mana salah satunya adalah akad ijab 
qabulnya satu majelis. Maksud satu majelis di sini adalah satu waktu dan satu tempat. Dan dengan syarat ini tentunya disyaratkannya tidak langsung begitu saja tanpa ada maksud, salah satunya nilai kesakralannya. Menurutnya dengan pengucapan ijab qabul seperti ini satu fenomena yang perlu dikaji secara mendalam dari banyak literatur-literatur fiqhi. Lanjutnya beliau juga menjelaskan jika memang ijab qabul online ini ingin dilakukan, akan lebih afdal menggunakan surat kuasa dari awal, surat kuasa tersebut dibuat di hadapan 2 orang saksi, sekaligus diketahui pihak KUA tempat Ijab dan Qabul dilaksanakan dan ditanda tangani di atas materai untuk dipergunakan nantinya pada saat akad ijab qabul. Hal ini akan lebih memudahkan persoalan pengurusan berkas administrasi pernikahan yang memerlukan pencatatan sesuai aturan yang berlaku. Meskipun begitu, nikah online tidak menutup kemungkinan bisa dilaksanakan dan dicatatkan, jika sudah ada putusan hakim yang telah memutuskan fenomena terkait. Sehingga KUA dalam hal ini sebagai pegawai pencatat nikah bisa mencatatkannya. Adapun mengenai keberadaan contoh kasusnya belum ada yang pernah terdaftar di KUA Kecamatan Panakkukang.

4. KUA Kecamatan Ujung Pandang Kepala KUA Ujung Pandang yakni Ust. Idil Fitri, menjelaskan bahwa Ijab qabul dalam proses akad nikah, jika telah memenuhi rukun dan syarat maka tidak dapat lagi diragukan keabsahannya. Karena kepastian hukumnya sudah ada, sesuai yang tercantum dalam UU Perkawinan. Lanjutnya, beliau memberikan analogi bahwa mewakili lewat surat saja boleh, apalagi dengan menggunakan teknologi yang bisa secara langsung menampakkan pisik dari kedua pihak yang melaksanakan ijab qabul tanpa adanya rekayasa.

5. KUA Kecamatan Makassar

Kepala KUA Kecamatan Makassar, Abd. Waris Usman, S.Ag., MA menjelaskan bahwa Ijab qabul via online ini fenomena baru yang dikarenakan perkembangan zaman. Perkawinan ijab dan qabul seperti yang kita dapatkan pada umumnya dan di berbagai literatur mempunyai nilai kesakralan, baik itu dari pandangan acara keagamaan dan adat.

Karena itu, nikah online yang tidak bersifat darurat, lebih baik ditunda pelaksanaannya, sampai kedua mempelainya mampu secara pisik dan mental hadir dalam satu majelis dan satu tempat. Tetapi, jika memang benarbenar darurat, maka bisa saja diperbolehkan dengan berbagai syarat, baik itu yang telah diatur oleh agama maupun yang diatur oleh pemerintah.

6. KUA Kecamatan Tamalate

Kepala KUA Kecamatan Tamalate yang diwakili oleh Drs. Iwan R, menjelaskan bahwa perkawinan di Indonesia diikat oleh 3 aturan yakni Agama Negara dan Adat. Aturan agama seperti yang diketahui mempunyai rukun-rukun dan syarat sahnya perkawinan agar sah. Begitu pun dalam aturan negara lewat UU Perkawinan dan Kompilasi Hukum Islam memiliki syarat mulai dari syarat administratif sampai sama seperti yang ditentukan oleh aturan agama. Mengenai ijab qabul via online ini secara agama sudah ada beberapa ulama kontemporer yang memperbolehkan karena menurut mereka tafsir satu majelis tidak harus satu tempat. Adapun mengenai pencatatannya, mulai kelengkapan 
berkas dan penandatanganan bisa diwakilkan melalui surat kuasa sesuai dengan pasal 10 ayat 2 PMA No 19 tahun 2018. Mengenai kasus nikah online di daerah Tamalate belum pernah ada yang melakukannya atau melaporkannya untuk dicatatkan secara resmi.

7. KUA Kecamatan Mamajang

Menurut Kepala Kantor Urusan Agama Kecamatan Mamajang Ust. Saifuddin Alwi S.Hi, ijab qabul via online ini satu model ijab baru yang kemudian mulai berkembang dimasyarakat karena perkembangan tekhnologi yang samakin canggih. Hal ini tidak bisa terelakkan, jadi baik hukum Islam maupun aturan negara juga harusnya mampu mengakomodir fenomena baru ini. Sesuai dengan kaidah yang populer ditelinga ummat muslim yakni "Al Islamussholih likulli zaman wa makan".

Mengenai pandangan hukum Islam itu sendiri, ada dua pendapat yang berkembang, pertama ijab dan qabul harus satu mejelis dan satu tempat. Kedua calon mempelai, wali, dua orang saksi harus satu majelis, dan pada saat pengucapan ijab qabul tidak boleh ada ucapan lain dan perbuatan yang memperantarainya. Kedua, ijab dan qabul tidak harus dilakukan antara dua pihak dalam satu tempat.

Di pendapat kedua ini, bisa disamakan dengan disahkannya oleh ulama imam mazhab terkait ijab qabul yang dilakukan oleh dua pihak yang berjauhan melalui sarana surat atau utusan. Oleh sebab itu, jika ijab qabul melalui surat saja disepakati kebolehannya oleh ulama mazhab, maka kenapa tidak ijab qabul yang menggunakan fasilitas $3 \mathrm{G}$ atau $4 \mathrm{G}$ yang melalui video call dll yang secara penggunaannya menampakkan wajah dari siapa yang diajak berkomunikasi melalu fasilitas itu.

Mengenai

pencatatan perkawinannya sekiranya menurut kepala KUA Mamajang akan tetap tercatatkan. Sederhananya Masa wakil dengan perwakilan bisa, apalagi melalui via online (video call, teleconference) yang jelas orangnya yang melakukan qabul dan melampirkan surat kuasa dan saksi yang melihat pengucapan qabul.

8. KUA Kecamatan Bontoala

Pandangan KUA Kecamatan Bontoala tentang nikah online, yang diwakili oleh Penghulu Madya, Ust. Ahmad Jazil menjelaskan bahwa, secara hukum Islam sudah banyak ulama yang berpendapat membolehkan, namun yang diperlu diketahui untuk di KUA seluruh Indonesia itu bukan hanya memakai hukum Islam saja tapi juga menggunakan hukum positif pada proses administrasinya. Ketentuannya jelas menurut beliau. Dalam Daftar Pemeriksaan Nikah itu mengharuskan adanya tanda tangan persetujuan kehendak perkawinan di mana secara langsung di tanda tangani oleh calon, begitu pun dalam Akta Nikah. Di mana akta nikah juga ada proses penandatanganan langsung oleh kedua pasangan setelah prosesi ijab dan qabul. Hal demikianlah secara Hukum positif menurut beliau belum bisa berkomentar banyak dikarenakan belum ada aturan yang jelas dan kasus yang terjadi untuk mau dicatatkan. Sehingga menurut beliau hal ini perlu dikaji lebih jauh agar fenomena seperti ini bisa mempunyai ketetapan hukum yang tetap.

9. KUA Kecamatan Tamalanrea

Menurut perwakilan dari Kepala KUA Kecamatan Tamalanrea, Fenomena Ijab qabul via onine ini merupakan hal yang sangat baru dan 
langkah. KUA Tamalanrea sendiri belum pernah mendapatkan kasus seperti ini. Secara hukum Islam sudah dibolehkan namun jika dalam kondisi tertentu dan memenuhi rukun syarat perkawinan. Adapun yang menjadi kendala terkait pencatatannya yakni pada proses pendaftaran, kelengkapan administratifnya sampai pembuatan akta yang dalam beberapa berkas mengharuskan kedua calon menandatangani secara langsung. Karena untuk saat ini, KUA di seluruh Indonesia menerapkan sistem yang begitu ketat sesuai aturan hukum positif yang ada dan digunakan oleh KUA seindonesia.

\section{KUA Kecamatan Manggala} Menurut Ust. Sambarani, S.Ag.MA selaku Kepala KUA menjelaskan bahwa mengenai problematika nikah online ini perlu dibedah secara detail, baik itu dalam kajian hukum Islam maupun hukum positif, karena belum ada kasus secara khusus yang terjadi di wilayah Kecamatan Mamajang. Dalam hukum Islam itu sendiri, perkawinan mempunyai 5 rukun dan syarat dan ke semuanya harus terpenuhi dalam proses akad nikah. Sehingga dianggap sah. Beda halnya dalam perspektif hukum positif, baik yang ada dalam UU Perkawinan maupun Kompilasi Hukum Islam meskipun dalam penentuan Rukun dan Syarat Perkawinan tidak mempunyai perbedaan, namun dalam hal lain khususnya pencatatan perkawinan mempunyai aturan tersendiri.

Beliau melanjutkan bahwa Probelematika kontemporer ini bisa saja dicatatkan dengan syarat pengucap qabul bisa dikenali dan jelas bahwa dialah mempelai prianya, dan dibuatkan surat kuasa untuk diwakilkan saat proses kelengkapan berkas dan lain sebagainya. Ini sama halnya dengan proses tawkil dalam perwalian. Dan menurut beliau hal ini tidak bertentangan dengan Aturan yang berlaku di Indonesia.

\section{KUA Kecamatan Tallo}

Menurut Perwakilan Kepala KUA Tallo Ust. Asnawi Arwan (penghulu kecamatan Tallo) menjelaskan bahwa hal yang terpenting diketahui adalah Aturan yang mengikat tentang perkawinan yang ada di Indonesia, ada dua yakni Hukum Islam dan hukum positif. Baik dalam hukum Islam dan hukum positif itu sendiri keduanya menyepakati bahwa yang menjadi Rukun dan Syarat sahnya sebuah perkawinan adalah adanya Calon mempelai laki-laki, calon mempelai perempuan, Wali Nikah, Dua Orang saksi dan Ijab dan qabul.

Hukum Islam menurut beliau, mungkin sudah banyak literaturlitaratur yang kemudian mengkaji dan membolehkan terkait Ijab Qabul via online ini asalkan dilakukan sesuai dengan metodologi (Rukun dan Syarat) yang sesuai dengan yang telah ditetapkan. Sedangkan dalam hukum positif, selain ketentuan rukun dan syarat harus terpenuhi juga perlunya melengkapi data materil (berkas kelengkapan) sebagai syarat administratif.

Adapun Ijab Qabul via online menurut beliau belum bisa tercatatkan karena akan terkendala pada proses administratifnya sesuai dengan ketentuan yang ada di dalam UU Perkawinan, Kompilasi Hukum Islam dan beberapa aturan lanjutan yang lebih khusus mengatur terkait pencatatan pernikahan itu sendiri. Di mana ada beberapa berkas yang mengharuskan kepada para calon untuk 
menandatanganinya secara langsung (Muslimin, 2016: 45).

Namun, ada opsi lain jika calon mempelai tidak dimungkinkan hadir yakni dengan membuat surat kuasa untuk diwakilkan dari awal pengurusan berkas sampai prosesi akad ijab qabul selesai. Hal ini dimungkinkan sesuai dengan aturan yang berlaku.

12. KUA Kecamatan Mariso

Menurut Kepala KUA Kecamatan Mariso yakni Ust. Abd. Rahman, S.Ag, Ijab qabul dalam proses akad nikah merupakan rangkaian dari Proses akad nikah yang masuk dalam Rukun Syarat sahnya perkawinan. Ijab qabul menurut beliau hal sakral dan sangat penting karena di situlah penyerahan amanah antara pengucap ijab (wali nikah) dengan Qabul (Mempelai laki-laki). Adapun terkait sah atau tidaknya proses ijab qabul via online ini, bisa dinilai dari dua pandangan. Yakni menurut Hukum Islam dan Hukum Positif yang berlaku di negara kita. Dalam hukum Islam terkait fenomena ini, ulama-ulama sudah banyak yang berkomentar. Ada yang membolehkan dalam tafsir bahwa ittihad al majelis ini satu waktu dan tidak harus satu tempat dan ada juga yang berpendapat sebaliknya yang mana tidak memperbolehkan karena tafsir ittihad al majelisnya harus satu waktu dan tempat.

Sedangkan dalam Hukum Positif yang berlaku di Indonesia, belum ada aturan jelas yang membahas wajib kah satu tempat dan waktu atau Cuma satu waktu dalam arti cukup kesinambungan pengucapan saja. Hal ini lah menurut beliau masih belum bisa mencatatkan jikapun memang kedepannya ada kasus. Bisa saja di catatkan tetapi diwakilkan dari awal mulai pendaftaran kehendak nikah sampai selesainya proses ijab dan qabul. agar supaya tidak menimbulkan polemik berkelanjutan atau ketidakjelasan (Gharar).

13. KUA Kecamatan Wajo

Menurut Kepala KUA Kecamatan Wajo yakni Dr. M. Ihsan Darwis, M.Si mengemukakan bahwa Ijab qabul via online adalah hal baru yang muncul akibat perkembangan ilmu pengetahuan di bidang teknologi. Sehingga segala hal di semua lini kehidupan secara tidak langsung ikut arus perkembangan tak terkecuali prosesi/tata cara pelaksanaan ijab qabul. Fenomena ini harus mendapatkan respons cepat baik itu dari segi pengkajian Hukum Islam maupun hukum positif yang berlaku di Indonesia. Sesuai dengan ketentuan atau aturan yang berlaku di negara kita. Perkawinan mempunyai Rukun dan Syarat untuk dapat dikatakan sah. Hal ini sesuai dengan beberapa literatur fiqhi yakni menetapkan 5 Rukun dan Syarat yakni Adanya mempelai lakilaki, mempelai perempuan, wali nikah, dua orang saksi dan Shigat Ijab Qabul.

Proses akad nikah yakni ijab qabul, mempunyai ketentuannya jelas, pengucap ijab dan qabul harus satu majelis dalam arti harus ada kesatuan tempat dan waktu, dan tidak adanya perbuatan apapun yang menghalangi ijab dan qabul itu sendiri. Sehingga jelas dan tegas ada kesesuaian dan jawaban langsung dari penyerah amanah (Wali nikah) dan penerimah amanah (Mempelai laki-laki). Begitupun dalam hukum positif yang berlaku. Pengucapan ijab dan qabul harus satu tempat dan waktu. hal ini karena banyaknya kelengkapan administrasi yang perlu diisi langsung oleh kedua mempelai. Orang yang menjadi saksi dapat melihat prosesi ijabnya. Jika calon mempelai laki-laki tidak bisa hadir maka dapat diwakilkan dengan menggunakan surat kuasa. Sehingga 
pengurusan administrasinya bisa berjalan lancar dan mempunyai legalitas yang kuat.

14. KUA Kecamatan Ujung Tanah Menurut Kepala KUA Ujung Tanah, Afdhal, S.Ag., MM. menjelaskan bahwa Ijab dan Qabul via online ini sudah sangat jelas hukumnya dengan banyaknya literatur fiqhi yang bisa kita baca dan dapatkan. Hal itu tentu bisa jadi rujukan untuk membantu hukum positif kita yang belum mengatur secara tegas terkait fenomena ini.

Pencatatan perkawinan terhadap ijab qabul via online yang sah tentu tetap bisa dicatatkan. Sepanjang rukun syarat sah perkawinan tersebut terlaksana, yaitu orang-orang yang melaksanakannya semua diketahui secara jelas. Penandatanganan berkas baik yang ada di DPN dan Akta tidak mempunyai ketetapan aturan yang jelas. Sehingga dimungkinkan untuk mereka yang mungkin melakukan ijab via online namun belum bertanda tangan secara langsung di akta nikah setelah proses akad nikah.

\section{PENUTUP}

Berdasarkan hasil penelitian dan pembahasan dapat diambil beberapa kesimpulan sebagai berikut:

Jika dikelompokkan maka dalam hukum Islam (ketetapan fiqhi) masih terjadi perbedaan pendapat mengenai pemaknaan "itihadu al majelis" dalam proses akad nikah dalam pengucapan ijab via online. Di mana jika merujuk kepada penafsiran yang pertama seperti yang dikemukakan di atas, persyaratan bersatu majelis oleh pendapat ini dipahami sebagai jaminan bagi kesinambungan antara ijab dan qabul. kesinambungan waktu antara ijab dan qabul, dapat terwujud dari dua tempat dengan memakai alat/media yang mampu menampakkan secara visual dan audio kepada seluruh orang yang menyaksikan ijab dan qabul itu. Agar para saksi dalam akad nikah tersebut dapat memastikan telah terjadi ijab dan qabul antara kedua belah pihak yang bersangkutan. Dengan cara demikian, persyaratan kesinambungan waktu, tempat dan pengucapan lebih dapat tercapai sehingga tidak ada kekhawatiran pemalsuan pengucap dan saksi juga menyaksikan secara langsung lewat media yang disediakan yakni Video Call dan lain-lain.

Apabila dilihat dari tafsir pendapat kedua, maka jelas praktik akad nikah via online ini tidak sah. Seperti yang telah dijelaskan di atas, bahwa pengucapan ijab qabul dalam akad nikah harus satu tempat dan waktu. atau dala istilah hukum Islam al muayyanah yakni berhadap-hadaan secara fisik. Untuk itu diisyaratkan bersatu majelis di samping adanya jaminan kesinambungan ijab dan qabul dan bersatu majelis. Karena dengan demikian terpenuhi dan terwujudnya satu tempat dan waktu secara fisik.

Dari hasil penelitian di atas khususnya mengenai pencatatan perkawinan ini, menunjukkan belum adanya sikap tegas dan kejelasan aturan dari pihak penyelenggara dan pencatatan perkawinan dalam hal ini Kantor Urusan Agama terkait pencatatan pihak yang kemudian melaksanakan ijab qabul via online. Padahal seperti yang telah dipaparkan di atas sudah adanya beberapa ulama klasik maupun ulama kontemporer yang memberikan sumbangsih pikirannya atas problematika kontemporer ini. Ditambah keputusan pengadilan agama Jakarta Selatan No.1751/P/1989 mengenai pengesahan Akad nikah 
melalui media telepon yang bisa diqiyaskan dengan kasus yang diangkat oleh peneliti. Perlunya hal demikian tidak lain memberikan angin segar bagi siapa pun yang ingin melaksanakan ijab qabul via online.

\section{DAFTAR PUSTAKA}

Amir, Syarifuddin. 2014. Hukum Perkawinan Islam di Indonesia Cetakan ke V Jakarta; Kencana.

Farid, Miftah, 2018. Nikah Online dalam Perspektif Hukum. Jurnal Ilmu Hukum Fakultas Syariah dan Hukum UIN Alauddin. Vol. 5, No. 1. Hal. 174-186.

Helim, Abdul, 2012. Membangun Fikih Progresif Mazhab Indonesia: Eksistensi Pencatatan Akad Nikah Dalam Hukum Perkawinan Islam Indonesia. In: Conference Proceedings: Annual International Conference on Islamic Studies (AICIS) XII, $5-8$ November 2012, Surabaya - Indonesia.

Ijab Qabul Lewat Video Call, https://m.detik.com/news/berita/d -3996092/kisah-haru-polwanijab-qabul-lewat-video-call, (diakses diakses pada 16 Maret 2019, pukul 23.37).

M.A.Tihami Sohari Sahrani. 2009. Fikih Munakahat 'Kajian fikih nikah lengkap' Jakarta; Rajawali Pers.

Muslim, Abu. 2014. Siasat dalam Perkawinan Masyarakat Sinjai. Tesis: UIN Alauddin Makassar. 2015. Kreatifitas Hukum Islam. Pusaka Jurnal Khazanah Keagamaan. Vol. 3 No. 2. Hal. 179-194.
Muslimin, Imam. 2016. Analisis Hukum Islam Terhadap Nikah Sirri Online. Undergraduate thesis, UIN Sunan Ampel Surabaya.

Rahayu, Nur Sari. 2017. Efektivitas pelaksanaan pasal 9 pma no 11 tahun 2007 tentang pencatatan nikah sebagai upaya meminimalisir pemalsuan identitas: studi kasus di KUA Simokerto Kecamatan Simokerto Surabaya. Undergraduate thesis, UIN Sunan Ampel Surabaya.

Rahman, Faiz, dan Faiza, Rizka Nur, 2014. Perkawinan Siri Online Ditinjau dari Perspektif Hukum Perkawinan Islam yang Berlaku di Indonesia. Jurnal Penelitian Hukum. Fakultas Hukum Gajah Mada. Vol 1, No. 1. Hal 37-49.

Sayuti, Thalib. 2014. Hukum Kekeluargaan Indonesia Jakarta; UI Press.

Slamet, Abidin dan Aminuddin. 1999. Fiqh Munakahat 1 Bandung: Pustaka Setia.

Subair, Muh. 2013. Optimalisasi Fungsi Dan Pengelolaan Masjid Islamic Center Kalimantan Timur. Pusaka Jurnal Khazanah Keagamaan. Vol. 1 No. 1. Hal. 57-68.

Az-Zuhaili, Wahbah. 2007. Fiqih Islam Wa Adillatuhu Jilid 9 Jakarta: Gema Insani \& Darul Fikir. 